\title{
CALORIMETRIC STUDY OF THE DIGITAL BLOOD FLOW IN CLUBBED FINGERS
}

\author{
BY \\ MORSI M. ARAB* \\ From the Department of Experimental Medicine, Guy's Hospital, London S.E.1 \\ Received March 30, 1963
}

Clubbing of the fingers has been the subject of interest among physicians since ancient times, yet the circulatory abnormalities involved are still far from settled. Mendlowitz (1941), using a Stewart calorimeter, followed the heat exchange during vasodilatation induced by indirect body heating in 35 cases and described a high blood flow in all except hereditary clubbing, and a decrease, often to normal levels, after cure or regression of the causative factors. Wilson (1952) confirmed these observations by applying a modified calorimeter similar to that described by Greenfield and Shepherd (1950) also after inducing vasodilatation by indirect body heating. There appear to be no reports of the digital circulation in clubbed fingers under other circumstances that might throw light on the condition of the digital vessels and factors controlling the circulation. Information of this nature was presented in a previous investigation where digital blood flow has been studied at rest, during reactive hyperæmia, and after sufficient indirect body heating to induce reflex hyperæmia by sympathetic inhibition in normal subjects and in patients with various abnormal vascular and nonvascular conditions: the special characteristic patterns of response have been reported (Arab, 1963). The present study is an extension of this to include the condition of clubbed fingers.

The blood flow in the resting finger was investigated to obtain indications of the digital circulation in clubbing at an environmental temperature of $28^{\circ} \mathrm{C}$. and to explore the response to a colder temperature of $20^{\circ} \mathrm{C}$., the latter being known to induce, in the normal state, marked vasoconstriction waves (Arab, 1963).

The blood flow was studied during reactive hyperæmia because in clubbed fingers there are reasons that lead us to expect a different type of behaviour. The association of a chronic state of anoxæmia in the cyanotic cases may be expected to modify the response to a temporary addition of more complete anoxæmia on obstruction of the circulation. Furthermore, the different connective tissue and vascular construction of the clubbed fingers (Lovell, 1950) may determine a qualitatively or quantitatively different response.

Finally, the maximal blood flow during indirect body heating was studied to obtain an induction of the patency and abundancy of the digital circulation.

\section{Subjects AND Methods}

Of the 17 patients in this study, 13 had clubbing associated with cyanotic congenital heart disease, and many of them had been already subjected to surgical treatment but all had residual cyanosis and clubbing of various degrees. Another patient had bilateral congenital hereditary clubbing. Three had acquired clubbing associated with pulmonary conditions.

Digital blood flow was studied according to the procedure described in a previous work (Arab, 1963) and was based on the principle of flow calorimetry. The apparatus used was the modified continuous flow calorimeter of Butterfield (1963). The test involved the continuous recording of resting digital blood flow at its highest (vasodilatation) and lowest (vasoconstriction) values. A period of temporary digital arterial

* This work was carried out while under a British Council Scholarship.

$2 \mathrm{w}+$ 677 


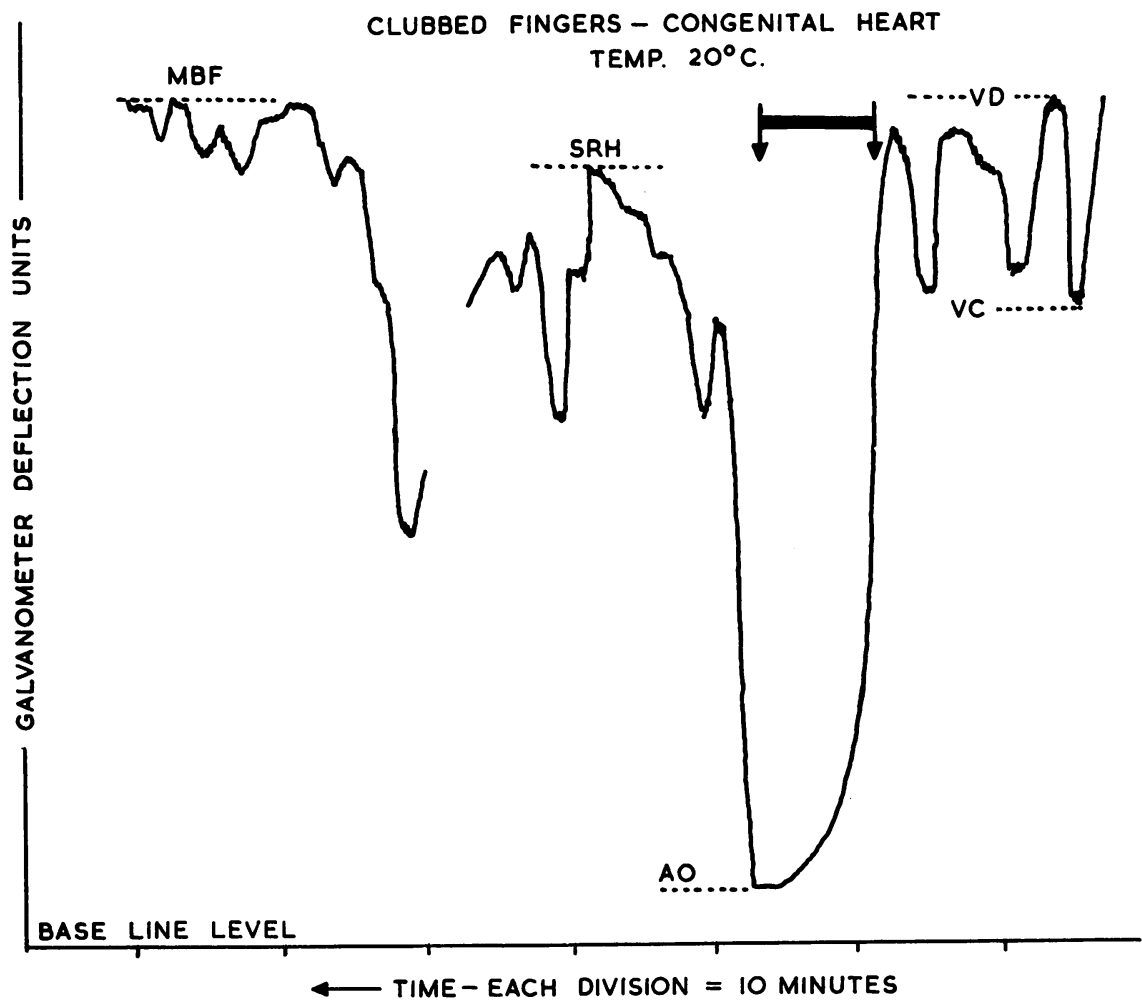

FIG. 1.-Digital blood flow in a case of clubbing due to congenital heart disease. MBF, maximum blood flow; SRH, standard reactive hyperæmia; VD, vasodilatation; VC, vasoconstriction; and AO, arterial obstruction.

ligation for eight minutes by digital tourniquet (arterial obstruction) was followed by a study of peak flow reactive hyperæmia after the release of the ligature (standard reactive hyperæmia) and finally the maximal digital blood flow after inducing reflex hyperæmia by indirect body heating (maximal blood flow). Fig. 1 exemplifies the procedure and gives typical results in a patient with clubbing due to congenital heart disease.

Three grades of clubbing were distinguished. Grade I: mild, when there was fluctuation at the nail bed with fullness of the angle. Grade II: moderate for a more advanced state with curvature of the nail. Grade III: severe, for drumstick clubbing. Table I gives a brief account of the cases studied.

\section{RESULTS}

Table II gives the mean of digital blood flows for eight of the congenital cyanotic heart cases and the three pulmonary cases tested at the temperature of $28^{\circ} \mathrm{C}$., based on observations made on the two middle fingers in each case. Mean flows are also shown as percentage values of the maximal blood flow obtained with body heating.

Table III gives similar results of digital blood flow for the other five cases of clubbed fingers of congenital heart and one of hereditary clubbing tested at $20^{\circ} \mathrm{C}$., and details of the latter results are shown in Fig. 2.

Fig. 3 shows a comparison of mean blood flows in the different types of clubbed fingers and in age-matched normal controls at $28^{\circ} \mathrm{C}$. and $20^{\circ} \mathrm{C}$. Control values are taken from a previous study using the same technique to establish normal patterns of the digital blood flow (Arab, 1963). For $28^{\circ} \mathrm{C}$. the means are those of eight subjects between the ages of 19 and 30 years, and for $20^{\circ} \mathrm{C}$. the means are those of the age-group 20-29 years. 
TABLE I

Clinical and laboratory Data for Cases of Clubbed Fingers

\begin{tabular}{|c|c|c|c|c|c|c|c|}
\hline $\begin{array}{l}\text { Type of } \\
\text { clubbing }\end{array}$ & Patient & Sex & $\begin{array}{c}\text { Age } \\
\text { (yrs.) }\end{array}$ & $\begin{array}{l}\text { Grade of } \\
\text { clubbing }\end{array}$ & $\begin{array}{l}\mathrm{Hb} \\
(\%)\end{array}$ & $\begin{array}{l}\text { Test } \\
\text { tempera- } \\
\text { ture }\left({ }^{\circ} \mathrm{C} .\right)\end{array}$ & Clinical notes \\
\hline \multirow{5}{*}{$\begin{array}{l}\text { Clubbing of } \\
\text { congenital } \\
\text { heart disease }\end{array}$} & J.K. & $\mathbf{M}$ & 19 & III & 115 & 28 & $\begin{array}{l}\text { Fallot; subclavian-pulmonary anasto- } \\
\text { mosis }\end{array}$ \\
\hline & $\begin{array}{l}\text { C.M. } \\
\text { R.D. } \\
\text { E.M. }\end{array}$ & $\begin{array}{l}\mathrm{F} \\
\mathrm{M} \\
\mathrm{F}\end{array}$ & $\begin{array}{l}21 \\
22 \\
24\end{array}$ & $\begin{array}{l}\text { II } \\
\text { III } \\
\text { I }\end{array}$ & $\begin{array}{l}110 \\
104 \\
110\end{array}$ & $\begin{array}{l}28 \\
28 \\
28\end{array}$ & $\begin{array}{l}\text { Fallot; innominate-pulm. anastomosis } \\
\text { Fallot; pulmonary valvotomy } \\
\text { Fallot; left subclavian-pulmonary anas- }\end{array}$ \\
\hline & $\begin{array}{l}\text { D.G. } \\
\text { P.C. }\end{array}$ & $\begin{array}{l}\mathrm{F} \\
\mathrm{M}\end{array}$ & $\begin{array}{l}20 \\
25\end{array}$ & $\begin{array}{l}\text { I } \\
\text { III }\end{array}$ & $\begin{array}{r}105 \\
90\end{array}$ & $\begin{array}{l}28 \\
28\end{array}$ & $\begin{array}{l}\text { tomosis } \\
\text { Fallot; infundibular resection } \\
\text { Fallot; right-sided aortic arch; Blalock's } \\
\text { operation; anæmia }\end{array}$ \\
\hline & $\begin{array}{l}\text { K.B. } \\
\text { E.B. } \\
\text { B.H. } \\
\text { G.H. }\end{array}$ & $\begin{array}{l}\mathrm{M} \\
\mathrm{F} \\
\mathrm{M} \\
\mathrm{F}\end{array}$ & $\begin{array}{l}23 \\
27 \\
21 \\
19\end{array}$ & $\begin{array}{l}\text { II } \\
\text { I } \\
\text { III }\end{array}$ & $\begin{array}{l}132 \\
124 \\
120 \\
105\end{array}$ & $\begin{array}{l}28 \\
28 \\
20 \\
20\end{array}$ & $\begin{array}{l}\text { Fallot; pulmonary stenosis } \\
\text { Fallot; subclavian-pulm. anastomosis } \\
\text { Fallot; old renal vein thrombosis } \\
\text { Fallot; subclavian-pulmonary anasto- } \\
\text { mosis }\end{array}$ \\
\hline & $\begin{array}{l}\text { D.W. } \\
\text { B.W. } \\
\text { M.N. }\end{array}$ & $\begin{array}{l}\mathbf{M} \\
\mathbf{M} \\
\mathbf{M}\end{array}$ & $\begin{array}{l}29 \\
25 \\
28\end{array}$ & $\begin{array}{l}\text { II } \\
\text { III }\end{array}$ & $\begin{array}{l}130 \\
120 \\
100\end{array}$ & $\begin{array}{l}20 \\
20 \\
20\end{array}$ & $\begin{array}{l}\text { mosis } \\
\text { Fallot; pulmonary valvotomy } \\
\text { Fallot; pulmonary valvotomy } \\
\text { Fallot; Blalock's operation }\end{array}$ \\
\hline $\begin{array}{l}\text { Hereditary } \\
\text { clubbing }\end{array}$ & D.W. & $\mathbf{M}$ & 28 & III & - & 20 & Clinically free; same condition in father \\
\hline \multirow[t]{2}{*}{$\begin{array}{l}\text { Broncho- } \\
\text { pulmonary } \\
\text { clubbing }\end{array}$} & $\begin{array}{l}\text { M.G. } \\
\text { A.J. }\end{array}$ & $\begin{array}{l}\mathbf{M} \\
\mathbf{M}\end{array}$ & $\begin{array}{l}29 \\
42\end{array}$ & $\begin{array}{l}\text { I } \\
\text { II }\end{array}$ & $\begin{array}{r}90 \\
102\end{array}$ & $\begin{array}{l}20 \\
20\end{array}$ & $\begin{array}{l}\text { Bronchiectasis } \\
\text { Emphysema; left thoracoplasty lobec- } \\
\text { tomy; tuberculosis }\end{array}$ \\
\hline & A.H. & $\mathbf{M}$ & 40 & III & 115 & 20 & $\begin{array}{l}\text { Nodular shadows in chest, sarcoidosis, } \\
\text { and ? alveocapillary block }\end{array}$ \\
\hline
\end{tabular}

TABLE II

Digital Blood Flow in Clubbed Fingers of Congenital Heart Disease and Pulmonary Disease at $28^{\circ} \mathrm{C}$.

\begin{tabular}{|c|c|c|c|c|c|c|c|}
\hline \multirow{2}{*}{$\begin{array}{l}\text { Type of } \\
\text { clubbing }\end{array}$} & \multirow{2}{*}{$\begin{array}{l}\text { No. of } \\
\text { cases }\end{array}$} & \multicolumn{2}{|c|}{ Sex } & \multirow{2}{*}{$\begin{array}{l}\text { Phase of } \\
\text { test }\end{array}$} & \multirow{2}{*}{$\begin{array}{l}\text { Range of digital } \\
\text { blood flow } \\
\text { (ml./min./c.c.) }\end{array}$} & \multirow{2}{*}{$\begin{array}{l}\text { Mean } \pm \text { standard } \\
\text { error }\end{array}$} & \multirow{2}{*}{$\begin{array}{c}\text { Maximum } \\
\text { blood flou } \\
(\%)\end{array}$} \\
\hline & & $\mathbf{M}$ & $\bar{F}$ & & & & \\
\hline $\begin{array}{l}\text { Congenital cyanotic } \\
\text { heart disease }\end{array}$ & 8 & 4 & 4 & $\begin{array}{l}\text { MBF } \\
\text { SRH } \\
\text { RVD } \\
\text { RVC } \\
\text { AO }\end{array}$ & $\begin{array}{l}0.24-0.86 \\
0 \cdot 22-0.71 \\
0 \cdot 20-0.67 \\
0 \cdot 13-0.54 \\
0.02-0 \cdot 10\end{array}$ & $\begin{array}{l}0.57 \pm 0.04 \\
0.42 \pm 0.04 \\
0.40 \pm 0.04 \\
0.26 \pm 0.04 \\
0.06 \pm 0.01\end{array}$ & $\begin{array}{l}100 \\
73 \cdot 3 \\
69 \cdot 6 \\
45 \cdot 2 \\
10 \cdot 5\end{array}$ \\
\hline Pulmonary disease & 3 & 3 & - & $\begin{array}{l}\text { MBF } \\
\text { SRH } \\
\text { RVD } \\
\text { RVC } \\
\text { AO }\end{array}$ & $\begin{array}{l}0 \cdot 26-0.40 \\
0 \cdot 11-0.33 \\
0 \cdot 15-0.22 \\
0.09-0.15 \\
0.01-0.04\end{array}$ & $\begin{array}{l}0 \cdot 32 \pm 0.02 \\
0 \cdot 21 \pm 0.04 \\
0 \cdot 18 \pm 0 \cdot 01 \\
0 \cdot 11 \pm 0 \cdot 01 \\
0 \cdot 02 \pm 0.004\end{array}$ & $\begin{array}{r}100 \\
67 \cdot 4 \\
55 \cdot 3 \\
34 \cdot 8 \\
7 \cdot 4\end{array}$ \\
\hline
\end{tabular}

MBF, maximum blood flow; SRH, standard reactive hyprræmia; RVD, resting vasodilatation; RVC, resting vasoconstriction; $\mathrm{AO}$, aortic obstruction 


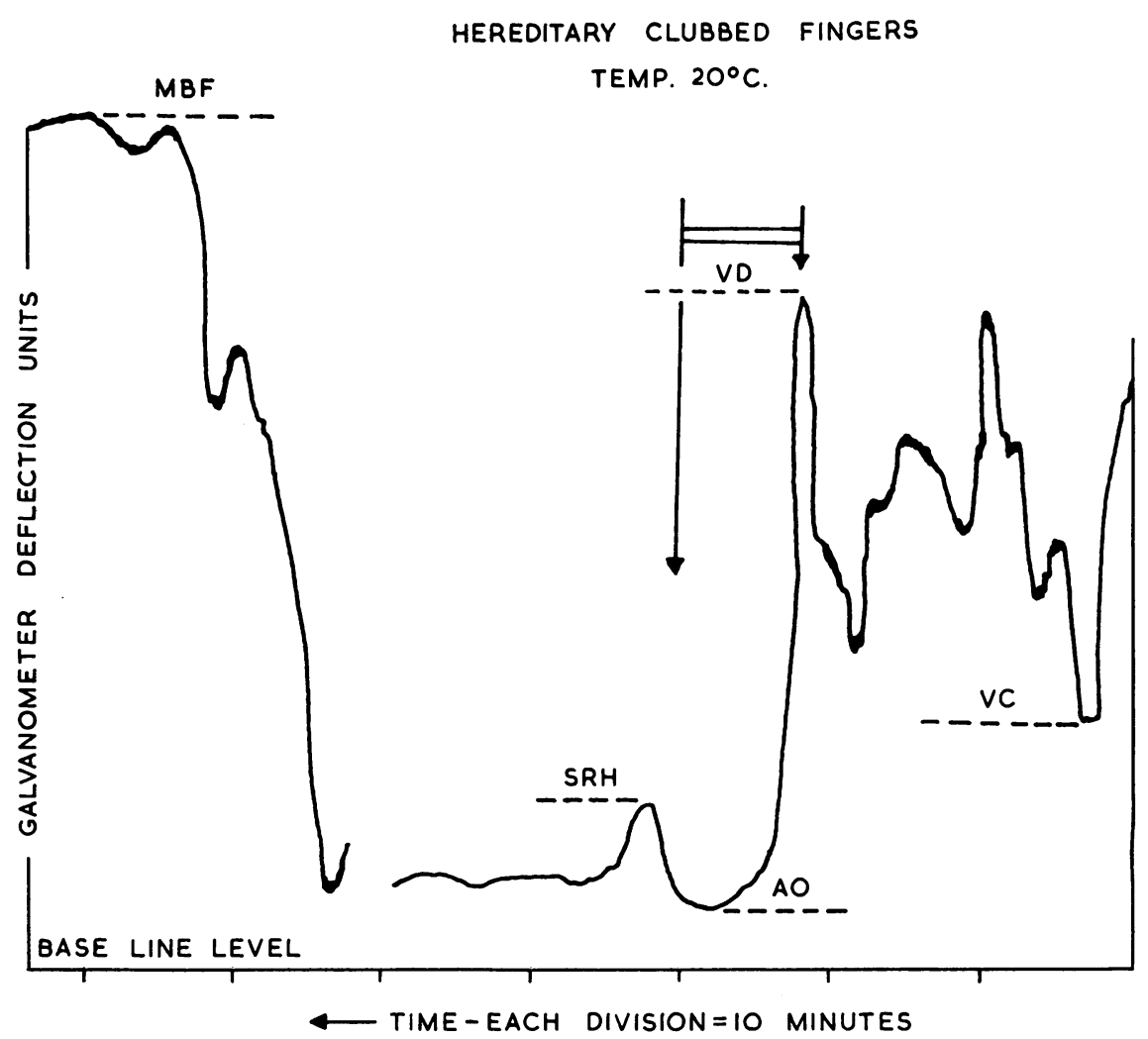

FIG. 2.-Digital blood flow in a case of hereditary clubbing. See Fig. 1 for key to lettering.

A correlation between the maximal blood flow and the degree of clubbing in the eight cases of clubbed fingers due to congenital heart disease, studied at $28^{\circ} \mathrm{C}$., showed the results presented in Table IV. The relation between the maximal blood flow for eight cases and the volume of the finger in the calorimeter for approximately the same length of finger in each subject is shown in Fig. 4.

TABLE III

Digital Blood Flow in Clubbed Fingers of Congenital Heart Disease and Hereditary Clubbing, at $20^{\circ} \mathrm{C}$.

\begin{tabular}{|c|c|c|c|c|c|c|c|c|}
\hline \multirow{2}{*}{$\begin{array}{l}\text { Type of } \\
\text { clubbing }\end{array}$} & \multirow{2}{*}{$\begin{array}{l}\text { No. of } \\
\text { cases }\end{array}$} & \multicolumn{2}{|c|}{ Sex } & \multirow{2}{*}{$\begin{array}{l}\text { Age } \\
\text { (yrs.) }\end{array}$} & \multirow{2}{*}{$\begin{array}{c}\text { Phase of } \\
\text { test }\end{array}$} & \multirow{2}{*}{$\begin{array}{l}\text { Range of digital } \\
\text { blood flow } \\
\text { (ml./min./c.c.) }\end{array}$} & \multirow{2}{*}{$\underset{\text { error }}{\text { Mean } \pm \text { standard }}$} & \multirow{2}{*}{$\begin{array}{c}\text { Maximum } \\
\text { blood flow } \\
(\%)\end{array}$} \\
\hline & & $\mathbf{M}$ & $F$ & & & & & \\
\hline $\begin{array}{l}\text { Congenital } \\
\text { cyanotic heart } \\
\text { disease }\end{array}$ & 5 & 4 & 1 & $21-29$ & $\begin{array}{l}\text { MBF } \\
\text { SRH } \\
\text { RVD } \\
\text { RVC } \\
\text { AO }\end{array}$ & $\begin{array}{l}0.44-0.91 \\
0 \cdot 21-0.51 \\
0 \cdot 27-0.46 \\
0 \cdot 11-0.26 \\
0.02-0.07\end{array}$ & $\begin{array}{l}0 \cdot 59 \pm 0 \cdot 05 \\
0 \cdot 37 \pm 0 \cdot 03 \\
0 \cdot 39 \pm 0 \cdot 02 \\
0 \cdot 18 \pm 0 \cdot 02 \\
0 \cdot 04 \pm 0 \cdot 004\end{array}$ & $\begin{array}{l}100 \\
62 \\
66 \cdot 1 \\
31 \cdot 2 \\
6 \cdot 2\end{array}$ \\
\hline $\begin{array}{l}\text { Hereditary } \\
\text { clubbing }\end{array}$ & 1 & 1 & - & 28 & $\begin{array}{l}\text { MBF } \\
\text { SRH } \\
\text { RVD } \\
\text { RVC } \\
\text { AO }\end{array}$ & $\begin{array}{l}0.33-0.37 \\
0.06-0.08 \\
0.21-0.23 \\
0.07-0.08 \\
0.02-0.02\end{array}$ & $\begin{array}{l}0.35 \\
0.07 \\
0.22 \\
0.08 \\
0.02\end{array}$ & $\begin{array}{r}100 \\
19 \cdot 5 \\
63 \cdot 2 \\
21 \cdot 8 \\
5 \cdot 7\end{array}$ \\
\hline
\end{tabular}


TABLE IV

Relation Between Maximal Blood Flow and Degree of Clubbing, at $28^{\circ} \mathrm{C}$.

\begin{tabular}{llll|c|c}
\hline \multicolumn{1}{c|}{ Degree of clubbing } & & $\begin{array}{c}\text { Number of } \\
\text { cases }\end{array}$ & $\begin{array}{c}\text { Mean maximum blood } \\
\text { flow } \\
\text { (ml./min./c.c.) }\end{array}$ \\
\hline Mild $\ldots$ &. &.. &. & 3 & $0 \cdot 76$ \\
Moderate &. & $\ldots$ &. & 2 & 0.58 \\
Severe &. &.. &. & 3 & $0 \cdot 39$ \\
\hline
\end{tabular}

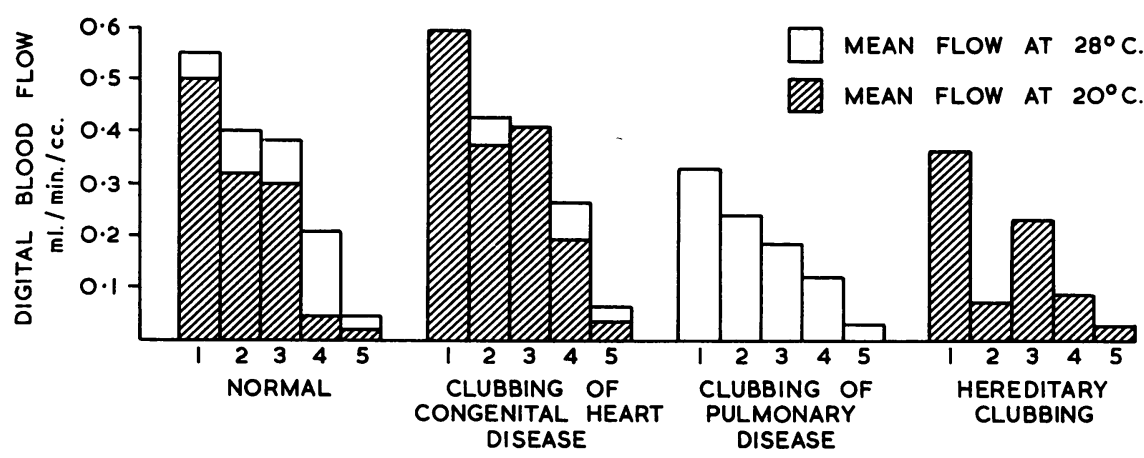

FIG. 3.-Mean digital blood flows in different types of clubbed fingers and in age-matched normal controls.

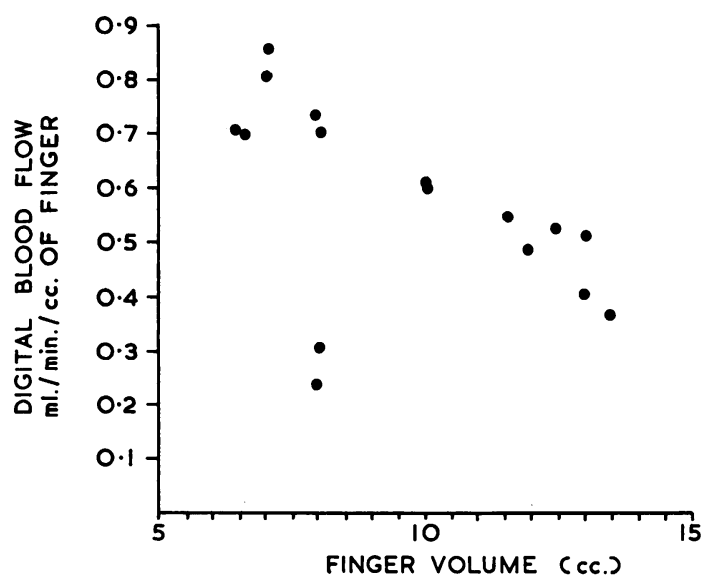

FIG. 4.-Relation between the maximal digital blood flow and finger volume in clubbing of congenital heart disease

\section{Discussion}

From the study of the above results the following conclusions may be drawn.

(a) As regards the maximal blood flows obtainable after indirect body heating, the mean values for clubbed fingers due to congenital cyanotic heart disease were above the normal level and for other types were below normal. Thus, there was a big difference between the mean maximal blood flow in the two different types, congenital cyanotic heart disease on the one hand and bronchopulmonary disease or hereditary clubbing on the other. This confirms the reports of Mendlowitz (1941) who noted that the blood flow in the hereditary type was not raised. It also accords with 
the structural difference between clubbing of congenital cyanotic heart disease and that of broncho-pulmonary disease reported by Lovell (1950). Through compression of the distal segment by an elastic bandage and recording the reducible volumes before and after this procedure, Lovell found that the blood content of the distal segments was increased in clubbing of congenital heart disease, but not in broncho-pulmonary disease. Furthermore, on histological examination he described a distinctive dilatation of the veins in clubbing due to congenital heart disease, which was not evident in broncho-pulmonary disease.

(b) The resting blood flows suggest that in clubbed fingers of congenital heart disease the reactivity of the digital circulation to cold is diminished, so the circulation remains at a more vasodilatated level with less marked vasoconstrictive oscillations than is the case in normal subjects. This is supported by analysis of the results presented in Fig. 3 .

Comparing the resting vasoconstriction values at $20^{\circ} \mathrm{C}$. with those obtained at $28^{\circ} \mathrm{C}$. it can be seen that whereas in the normal cases the flow drops at $20^{\circ} \mathrm{C}$. to less than a quarter of its $28^{\circ} \mathrm{C}$. value, in clubbing of congenital heart disease it only falls to about three-quarters of the $28^{\circ} \mathrm{C}$. flow. Thus these resting vasoconstriction values at $20^{\circ} \mathrm{C}$. will be found to be much higher in clubbing of congenital heart disease than in the normal state (amounting to about four times the normal value). The resting vasodilatation flows in clubbed fingers of congenital heart disease did not show an appreciable departure from normal. It may be concluded that there is diminished power to vasoconstrict in this form, but whether this causes clubbing or simply results from it we cannot tell at present.

(c) The digital blood flow during reactive hyperæmia did not show any appreciable difference between normal cases and clubbed fingers of congenital heart disease or broncho-pulmonary disease when expressed as percentages of the maximal blood flow. In sharp contrast the hereditary clubbing showed a diminished reactive hyperæmia with a peak flow even lower than the resting vasoconstriction value. Moreover, ischæmia was followed by a long period of vasoconstriction during which the usual vasodilatation waves were nearly absent (Fig. 2). This suggests that in this particular form of clubbing there is a special factor, probably resulting from the abnormal tissue construction, that has masked the vasodilator response to reactive hyperæmia or even induced vasoconstriction. The nature of this factor is at present the subject of further study.

The inverse relation demonstrated between the degree of clubbing in congenital cyanotic heart disease and the maximal digital blood flow per unit of volume (Table IV) may be due simply to the greater volume of finger in the severer grades, since there is also an inverse relation between the maximal blood flow and the finger volume (Fig. 4). It must not be taken as evidence of diminished total blood flow in the clubbed fingers in severer grades: this is in fact higher in more advanced clubbing but probably not increasing to the same extent as the increase of volume of the finger.

\section{SUMMARY}

The digital blood flow of clubbed fingers was studied in thirteen cases of congenital cyanotic heart disease, three of broncho-pulmonary disease, and one of hereditary clubbing. A continuous flow calorimeter was used and patterns of the digital circulation at rest, temporary arterial obstruction, reactive hyperæmia, and reflex hyperæmia induced by indirect body heating were compared with the normal state. The results suggest the following conclusions.

(1) The maximal digital blood flow obtained after body heating in clubbing of congenital heart disease is slightly greater than the normal and much greater than other types of clubbing. The distinction between the two types of clubbing is discussed in the light of previous reports of structural difference.

(2) The resting digital blood flow suggests that in clubbing of congenital cyanotic heart disease the digital circulation is less responsive to cold. The capacity to vasoconstrict seems to be diminished and the digital blood flow thus remains at a more "dilated" level. 
(3) The response to temporary circulatory obstruction was similar to the normal form except in hereditary clubbing where it induced a very poor reactive hyperæmia followed by a persistent vasoconstrictive state. The factor responsible for this phenomenon is suggested to lie in the special tissue construction of this form of clubbing, although its nature is yet to be investigated.

I wish to acknowledge my indebtedness to Professor W. J. H. Butterfield under whose direction this work was carried out. I am also grateful to Dr. D. C. Deuchar of the Cardiac Department for his great help in referring cases of congenital heart disease. My thanks are due to Miss D. Bruce for technical assistance.

\section{REFERENCES}

Arab, M. M. (1963). A calorimetric study of the digital blood flow in normal subjects and in some abnormal vascular and nonvascular conditions. Guy's Hosp. Rep. In the press.

Butterfield, W. J. H. (1963). A continuous water flow calorimeter for finger blood flow studies. Guy's Hosp. Rep. In the press.

Greenfield, A. D. M., and Shepherd, J. T. (1950). A quantitative study of the response to cold of the circulation through the fingers of normal subjects. Clin. Sci., 9, 323 .

Mendlowitz, M. (1941). Measurements of blood flow and blood pressure in clubbed fingers. J. clin. Invest., 20, 113.

Lovell, R. R. H. (1950). Observations on the structure of clubbed fingers. Clin. Sci., 9, 299.

Wilson, G. M. (1952). Local circulatory changes associated with clubbing of the fingers and toes. Quart.J. Med., (n.s.), 21, 201. 